\title{
Como morrer em vida: performances literárias da morte
}

\author{
Aline Leal Fernandes Barbosa*
}

\begin{abstract}
Resumo
O erotismo, o sagrado e a morte são temáticas centrais nas obras de Hilda Hilst e Georges Bataille. Além disso, são modos performáticos da linguagem, sua tendência incontinente, seu excesso. Está aí o ponto crucial em que se encontram: a extremidade que perseguiram como via inevitável de criação. Neste artigo debruça-se sobre algumas cenas da morte - como experiência radical da continuidade evocada pelo erotismo e o sagrado - como princípio de dissolução dos limites fundadores do mundo, de destruição da descontinuidade constitutiva. Trata-se, assim, de refletir sobre os movimentos de perturbação, desorganização e despossessão nas obras desses autores.

Palavras-chave: Erotismo. Sagrado. Morte. Hilda Hilst. Georges Bataille.
\end{abstract}

\section{How to die in life:the literary performances of death}

\begin{abstract}
Eroticism, sacredness and death are central themes in the works of Hilda Hilst and Georges Bataille. They are operative modes of language, its incontinent tendency, its excess. The crucial point in which Bataille and Hilst meet: the extremity they pursued as an inevitable way of creation. This article presents some performances of the death - as the principle of dissolution of the founding limits of the world, as a destruction of the constitutive discontinuity. Doing so, we aim to reflect on the movements of disruption, disorganization and dispossession in the works of these two authors.
\end{abstract}

Keywords: Eroticism. Sacred. Death. Hilda Hilst. Georges Bataille.

Recebido: 31/01/2019

Aceito: 01/04/2019

* Pontifícia Universidade Católica do Rio de Janeiro (PUC Rio). Pós-Doutora (Bolsista Capes/PNPD, 2019), Doutora (2017) e mestra (2013) pelo programa de Literatura, Cultura e Contemporaneidade da PUC-Rio. 
"Mas não é a cada dia que morre um irmão."

HILST, 2003

Irmão de Marta e Maria, Lázaro de Betânia teve, dentre os homens, o destino de quase nenhum outro: o de morrer duas vezes. Sepultado havia quatro dias no interior de uma rocha, ele é ressuscitado por seu amigo Jesus, quando ordena: “Lázaro, vem para fora!”. Subverte-se, assim, a passagem bíblica que diz: "aos homens está ordenado morrerem uma só vez, vindo, depois disso, o juízo" (HEBREUS: 9:27). Lázaro é uma derivação grega do nome hebraico "Elzeário", que significa Deus ajudou".

Hilda Hilst dedicou um conto homônimo ${ }^{1}$ a essa personagem bíblica, o terceiro de seu primeiro livro de prosa Fluxo-floema (1970). Lázaro é o narrador em primeira pessoa que nos relata a passagem da vida à morte, com a acuidade de quem a experienciou: "Primeiro um golpe seco na altura do coração. O espanto de sentir esse golpe. Os olhos se abrem, a cabeça vira para o lado, tenta erguer-se e dá tempo de perceber um prato de tâmaras na mesa comprida da outra sala. Dá tempo de pensar: alguém que não eu vai comer essas tâmaras" (HILST, 2003, p. 112). E então a vida em seus últimos momentos é descrita até a visão final: "Ainda vejo a cabeça de Maria na beira da cama. A cabeça cheia de cabelos escuros na beira da cama. Foi a última coisa que vi: a cabeça de Maria" (HILST, 2003, p.112). Lázaro não está mais morrendo, Lázaro está morto.

Há certo tom de trivialidade nessa cena, pois, se não é a cada dia que morre um irmão, milhões de irmãos morrem a cada dia: a face cotidiana e ordinária da morte. Lázaro conta-nos do encontro com seu outro eu, o duplo de Lázaro pós-morte: Rouah, "alguém feito de mim mesmo e de um Outro" (HILST, 2003, p. 114). Rouah é um corpo estranho, um ser sexuado (de sexo peludo e volumoso), obsceno e repulsivo, e Lázaro lhe implora: "irmão gêmeo Rouah, eu preciso voltar, eu devo voltar" (HILST, 2003, p. 121). E então temos diante de nós um ser ressuscitado, de volta ao mundo dos vivos após ter conhecido a morte, ali onde "vê-se em profundidade" (HILST, 2003, p. 113). Morrer, no conto, é encontrar-se com seu outro eu, com sua alteridade, defrontar-se com seu próprio corpo, já outro. O ser pessoal é destruído, e a morte é uma revelação.

Além da dimensão carnal e espiritual, há a dimensão ritual da morte: o que fazer com esse corpo, como encaminhá-lo à morte diante dos vivos? Marta, em sua disposição implacável, soube fazê-lo muito bem, "ela soube fazer a minha morte, ela soube colocar tudo, como se coloca tudo no corpo de alguém que morre" (HILST, 2003, p. 111). Lázaro elenca os procedimentos cerimoniosos: "Primeiro ela tirou a minha roupa. E tirar a roupa de um morto é colocar outra. Depois lavou-me. Depois escolheu as essências" (HILST, 2003, p.111). O corpo de Lázaro é enfaixado e, por fim, colocado em uma gruta, "buraco fundo".

Georges Bataille identifica, em O erotismo [1957] (2014), o ato da inumação e o costume da sepultura como testemunho de um interdito concernente aos mortos, cujo surgimento coincide com a desaparição do Homem de Neandertal (o Homo faber), ${ }^{2}$ no fim do Paleolítico Médio, e a vinda do Homo Sapiens, o homem semelhante a nós. Trata-se de assinalar uma diferença entre o cadáver humano e os outros objetos, e a diferença do homem em relação ao animal: "o que chamamos de morte é em primeiro lugar a consciência que temos dela. Percebemos a passagem do estado vivo ao cadáver, ou seja, ao objeto angustiante que é para o homem o cadáver de outro homem" (BATAILLE, 2014, p. 68). O horror aos mortos é decorrente da evidência da violência intrínseca à morte e de seu contágio irrestrito e irrecuperável, além disso, da consciência adquirida de sua podridão porvir: "Para cada um daqueles que fascina, o cadáver é a imagem de seu destino. Ele testemunha uma violência

1 É interessante que este conto seja dedicado ao seu amigo Caio Fernando Abreu, cujo espírito Hilst relata ter visto no dia de sua morte: "Ele morreu à uma hora e veio se despedir às dez da noite. A gente tinha combinado isso. Ele veio com o cachecol que tinha uma fita vermelha. [...] o vermelho ia significar que estava tudo bem", mas em seguida Hilst se queixa da repercussão de suas visões na boca dos outros: "Falam: A Hilda é uma bêbada, uma alcoólatra, está sempre louca" (DINIZ, 2013, p. 204).

2 Que viveu 100 mil anos antes de nós. 
que não apenas destrói o homem, mas que destruirá todos os homens” (BATAILLE, 2014, p. 68).

Bataille indica ainda que o nascimento deste interdito teria coincidido com o nascimento do trabalho, na medida em que, aliado à razão, o trabalho regula a violência de que a morte é originária e a desordem que a morte instaura. O trabalho refreia a violência do desejo e sua solicitação imediata e, por sua vez, solicita ganhos no tempo ulterior. Assim, controla-se a desordem da morte a fim de ordená-la nos limites do que a razão acolhe, instaurando o interdito e seus dispositivos de atração e recusa: "Aquilo que, com o trabalho, esse homem reconheceu de pavoroso e transformador - e mesmo de maravilhoso - é a morte" (BATAILLE, 2014, p. 67).

A morte, signo da ruína do mundo, escancara a violência que esse mundo se aplica em encobrir. Reside aí, portanto, uma ambiguidade: se a consciência da morte é uma das pedras fundamentais deste mundo, a morte é igualmente recusada, na medida em que sua violência ameaça nossa "civilização suavizada" (BATAILLE, 2014, p. 70). Assim, os rituais surgiriam a fim de suavizar o horror e o fascínio que tal instância provoca, indicando uma medida possível para o que é de caráter impossível, para o que é, sem dissimulação, impossível, para nós, sustentar. Isso porque, ainda que seja atraído pelo abismo da continuidade - fascinante e vertiginoso - o ser apega-se firmemente à descontinuidade que o faz durar, mas essa é uma situação perecível.

A violência será o princípio dos movimentos de dissolução dos limites fundadores do mundo, de destruição da descontinuidade constitutiva do ser, de que a morte é a experiência radical, e o erotismo, na fusão dos corpos e no desencadeamento de impulsos destrutivos, uma de suas manifestações. Bataille observa: "O erotismo abre para a morte. A morte abre para a negação da duração individual. Poderíamos, sem violência interior, assumir uma ligação que nos conduz ao limite de todo o possível?" (BATAILLE, 2014, p. 47). O erotismo será um face a face com a morte e desvelará o seu segredo: a abertura à continuidade ininteligível, incognoscível... intragável.

$\mathrm{Na}$ introdução ao Erotismo, Bataille cita duas vezes a frase do Marques de Sade "Não há melhor meio de se familiarizar com a morte do que aliá-la a uma ideia libertina" (SADE apud BATAILLE, 2014, p. 36), que marca com exatidão o princípio que liga morte e excitação sexual. A experiência da sexualidade em Sade se dará sob o signo da transgressão, que terá na violência, no excesso e na desordem condutores de extravasamento e êxtase. Os objetos do desejo conduzirão ao suplício da morte, apontando para o que Bataille destacou como a verdade da obra sadiana: "que traz a má nova de um acordo dos vivos com aquilo que os mata, do Bem com o Mal, e se poderia dizer: do grito mais forte com o silêncio" (BATAILLE, 2015, p. 104). Assim, deparamo-nos com uma linguagem que excede a possibilidade de dizer, provocando um esgarçamento do discurso, com momentos em que horror e felicidade coincidem, elevando o sentimento ao seu clímax, em que o ser é dado no seu ultrapassamento, para além de suas limitações.

O próprio assassinato é evocado com atrativo e volúpia, como inflamador de paixões capaz de realizar um desencadeamento radical nas ordens do trabalho e da decência. Torturar, humilhar, matar? Tudo é possível aos olhos de Sade, desde que resulte em prazer. O interdito não será capaz de sufocar aquilo que refreia, podendo, inclusive, ser seu multiplicador: o tamanho dos limites impostos ao desejo será o tamanho da libertinagem disparada. O ser transgressor do interdito será atingido por uma maldição, no entanto "a maldição é a condição de sua glória [...] como se o interdito nunca fosse mais do que o meio de atribuir uma gloriosa maldição àquilo que ele rejeita" (BATAILLE, 2014, p. 72). Assim, haverá uma recompensa libidinal ao ser maldito.

Em sua obra, Sade avança sobre a ideia da morte de Deus. Dessa questão, faz o ponto de partida de toda a sua reflexão, de toda a sua liberdade. Sem Deus, o homem não é mais o ser à sua imagem e semelhança e, portanto, não ocupa mais o topo da hierarquia, e será, assim, "apenas" um animal entre os outros. De modo que se pode afirmar: 
De seu desejo incontrolável, Sade chega a conclusões próximas às das Luzes, exceto que ele também expressa suas consequências mais sombrias: se o homem é a natureza, a violência da natureza é natural para ele, e a crueldade, o fim, a morte, portanto, também lhe são naturais, no que permitem que o ciclo de vida se perpetue. ${ }^{3}$ (RESSOUNI-DEMIGNEUX, 2014)

Logo, para Sade o sublime será encontrado no coração das paixões humanas, onde coexistem desencadeamentos a princípio inconciliáveis. Sade será, assim, o modelo exemplar da profanação sem Deus. Também o sagrado apresentará semelhante movimento de dissolução, tendo de igual forma a violência como pedra de toque, como aponta Bataille (BATAILLE, 2014, p. 45): "O sagrado é justamente a continuidade do ser revelado aos que fixam sua atenção, num rito solene, sobre a morte de um ser descontínuo", indicando a imolação da vítima no sacrifício como o momento de ruptura da descontinuidade. No mundo moderno, sustenta Bataille, o sagrado dos sacrifícios primitivos será o divino das religiões. Trata-se, portanto, de situações em que o ser descontínuo precipita na continuidade do ser.

Erotismo, sagrado, morte: movimentos performáticos de perturbação, desorganização, despossessão, instaurando o espaço que Bataille (2014, p. 47) chamou de "encruzilhada de violências fundamentais". Ora, Lázaro atravessa tais instâncias e narra essa travessia como quem falasse de um outro, como quem visse de fora, embora essa exterioridade lhe diga respeito. Aponta-se, assim, para o intervalo aberto entre dois pontos do espectro, para a ferida aberta da dilaceração, a densidade da linha de transgressão: "O meu corpo foi depositado no seu lugar. Estou acima dele, a uma pequena distância. Pairo sobre ele” (HILST, 2003, p.116). Desse encontro dissociado, ele diz: "Ele é alguém feito de mim mesmo e de um Outro", e em seguida diz: "O outro, eu não lhes saberia dizer o nome. O Outro não tem nome. Talvez tenha, mas é impossível pronunciá-Lo” (HILST, 2003, p. 114). Assim, ainda que seja possível pressenti-lo, ainda que Ele seja também um "si próprio", essa propriedade lhe é exterior, e não será possível fazê-lo palavra, organizá-lo na disposição da linguagem, apontando para sua insuficiência abissal. Em um ato de falsificação, será preciso rebatizá-lo, portanto: Rouah.

Ele - o Outro - é com maiúscula que se escreve, indicando um ser soberano e transcendental. Mas é interessante a ruptura que, ao longo do conto, se dá em relação a essa instância. Em sua travessia, Lázaro aporta entre os monges do último convento sobre a terra, e só então fica a par do cruel destino de Jesus, a partir de uma imagem na parede, da imagem de todas as paredes da casa: o filho de Deus crucificado com uma coroa de espinhos na cabeça. Mas a novidade é ainda mais drástica: não importa o nome que se lhe queira dar - Jesus, Rouah, Azezel, Keteb, Alukah - o que se sabe agora é que ele não existe, que ele nunca existiu: "Escuta, filhinho, Lázaro meu filhinho, o Jesus de quem falas está morto há muito tempo, e para os homens de agora nunca ressuscitou, nem está em lugar algum nem... não te aborreças, mas... sabemos que Ele... que Ele nunca existiu, Ele foi apenas uma ideia, muito louvável até, mas... Ele foi apenas uma tentativa de...” (HILST, 2003, p. 137).

Sem Ele, a morte ganha uma tonalidade bastante mais dramática, e até mesmo os monges a receiam: "sabendo toda a verdade a morte fica uma coisa bem triste, apesar de que a vida também não tem muito interesse, mas, enfim, antes, antes era belo morrer porque poderíamos vê-Lo, tocá-Lo, amá-Lo por toda a eternidade, mas agora... a morte não é nada" (HILST, 2003, p. 138). Assim, a inexistência de Deus aponta aqui também para a inexistência da morte, uma vez que seu imaginário finamente elaborado tomba quando seu principal sustentáculo é varrido da cena. E logo a inexistência de Deus

3 Este trecho foi retirado do artigo "Fin du XVIII siécle - La Révolution libère les pulsions destructrices" (pág 17-20), de Karim Ressouni-Demigneux, para a revista Sade - Attaquer le soleil, publicada pelo Musée d'Orsay por ocasião da exposição homônima ocorrida neste museu, de 14 de outubro de 2014 a 25 de janeiro de 2015 . Nesse artigo, seu autor ressalta a cena histórica pré-Revolução Francesa como disparadora da obra sadiana, portadora da violência revolucionária. Para Georges Bataille, no artigo que escreveu sobre Sade em A literatura e o mal, a Tomada da Bastilha, as prisões de Sade que somam quase 30 anos de encarceramento, ligam a vida e a obra de Sade "de maneira estranha". 
e da morte instauram o lugar de uma nova existência, doravante encarada sob essa ausência, vivida no espaço desse vazio projetado.

Mais uma vez a morte de Deus: Michel Foucault vai tratar deste tema em "Prefácio à transgressão", ensaio publicado na revista Critique, em homenagem ao seu fundador, George Bataille, em 1963, um ano após a sua morte. Nesse texto, a experiência da sexualidade, pensada sob o signo do excesso e da transgressão, delineará o que se constitui como a experiência moderna: aquela da morte de Deus. Suprimido o limite do ilimitado, retirada da linguagem a palavra que ultrapassa todas as palavras, o vazio deixado em sua esteira será o espaço do reencontro contínuo do limite com a sua transgressão. Assim, afirma-se a interdependência entre a fronteira e a sua ultrapassagem, sua cumplicidade intrínseca e inextinguível, seu tratado eterno de convivência.

Foucault discorre sobre isso: “A transgressão é um gesto relativo ao limite; é aí, na tênue espessura da linha, que se manifesta o fulgor de sua passagem, mas talvez também sua trajetória na totalidade, sua própria origem. A linha que ela cruza poderia ser também todo o seu espaço" (FOUCAULT, 2001, p. 30). Assim, o espaço da experiência moderna será o do encontro do limite com a sua violação, com toda a violência que este gesto deve implicar. Mas a ideia lança-se ainda além: esse espaço - essa experiência - só será de fato compreendido uma vez rasgado e atravessado, no momento mesmo de sua dilaceração. Isto é, a experiência se dará no momento em que o sujeito vai ao encontro do seu limite, em que o chifre do touro perfura a órbita do toureador, no instante em que os corpos atingem o gozo frívolo, em que o ser se vê, como Lázaro, remetido à própria morte. De modo que, na experiência moderna, o sujeito não será formado ou protegido, porém supliciado e destruído. E assim a morte de Deus será também a morte do sujeito.

O encontro entre os vivos e os mortos se dá na maior parte da escrita ficcional de Bataille, sobretudo na chave da excitação sexual. Em A história do olho (1928), dá-se a seguinte cena de perversão: "Voltamos ao quarto, ela tinha se enforcado dentro do armário. Cortei a corda, ela estava bem morta. Nós a colocamos em cima do tapete. Simone me viu de pau duro e me bateu uma punheta; deitamos no chão e eu a fodi ao lado do cadáver" (BATAILLE, 1981, p. 53). Isso para não falar da passagem em que o narrador, Simone e Sir Edmond atacam sexualmente um padre até a morte, em uma cena com toques de necrofilia: "O esperma do morto escorrendo pelas coxas. Deitei-me para fodê-la também. Estava paralisado. Um excesso de amor e a morte do miserável tinham me esgotado. Nunca fiquei tão satisfeito"; e em seguida: "A moça teve vontade de contemplar a sua obra e me afastou para se levantar. Montou outra vez, de cu pelado, em cima do cadáver pelado” (BATAILLE, 1981, p. 73).

Também em Hilda Hilst a morte e a excitação sexual poderão apresentar ligações profundas. Em Contos d'escárnio, textos grotescos (1990), segundo livro da trilogia erótica, a cena de abertura já evoca a dobradinha sexo-morte na vida do ser que nasce, se reproduz e morre: o pai de Crasso morre em um bordel em cima de uma puta peituda e rebolante, e, mais adiante na narrativa, Crasso se pergunta em retrospecto sobre a repercussão dessa ocorrência em sua vida: "Será que porque o pai morreu em cima de uma puta eu ia ficar em cima das mulheres o tempo todo?” (HILST, 2016, p. 77). Por sua vez o preceptor de Crasso, o tio Vlad, tem também uma morte que não reclama decência, que não poupa sua vítima de embaraços sexuais: "Tio Vlad morreu quando estava sendo chupado por um coroinha lá na Grota do Touro, um lugarejo muito longe daqui” (HILST, 2016, p. 72). Bocó, um cara de boca fofa, foi quem espalhou a notícia: "Seu Vlad tá morto com a minhoca pra fora lá na Gota do Touro" (HILST, 2016, p. 74). Em uma carta à Clódia, sua amante, pintora de vaginas e pintos, Crasso expõe sua vontade de proteger o pensamento de ideias deletérias: "Saber da própria morte, por exemplo, é uma maçada. A profusão de vermes e de asas que espoucarão no meu corpo-monturo". Então Crasso propõe a criação de uma geringonça que desse conta disso: "A morte arrancada do cérebro. Olharíamos o morto e seria como se olhássemos uma travessa de alfaces. Comer o morto seria até melhor do que sabê-lo" (HILST, 2016, p. 107). 
Negar a morte. Sabemos que para Hilda Hilst o livro seminal de Ernest Becker - A negação da morte (1973) - teve uma importância fundamental, e ela não cansou de citá-lo e exaltar a genialidade do escritor em diversas entrevistas que deu. Em um encontro que Nelly Novaes Coelho (1989) organizou ${ }^{4}$ uma das críticas literárias contemporâneas à autora que mais prestou atenção em sua obra, Hilda Hilst diz:

Há um homem de que eu gosto muito, que parece ter vindo de uma outra galáxia. Chamase Ernest Becker. Escreveu um livro chamado A negação da morte, que considero um dos maiores livros escritos nestas décadas. Ele diz que o homem é o animal mais devastador que existe sobre a terra, porque deseja um destino incompatível com o animal, que é o que ele é: um animal. (DINIZ, 2015, p. 114).

São tantos os elogios conferidos a Becker que o leitor de Hilda Hilst fica interessado em conhecer este autor e saber de seu pensamento sobre a morte e o ser humano que vive destinado a essa fatalidade. Na página de 22 de janeiro de 1979 de uma agenda (FIG. 1), ${ }^{5}$ Hilst escreve sobre o impacto desta leitura: "Releio Ernest Becker. Incrível. Mas se toda essa minha experiência é a dimensão depois da morte, então é preciso pensar tudo de novo. Por que o consciente não registra o espaço-tempo morte como o inconsciente? O inconsciente se pensa imortal? Por quê?" E depois Hilst faz uma pequena lista de "irmãos": Franz Kafka, Ernest Becker, Samuel Beckett, Nikos Kazantzakis, Carl Gustav Jung, Hermann Broch.

Figura 1: Em página de agenda, HH expressa sua admiração por Ernest Becker

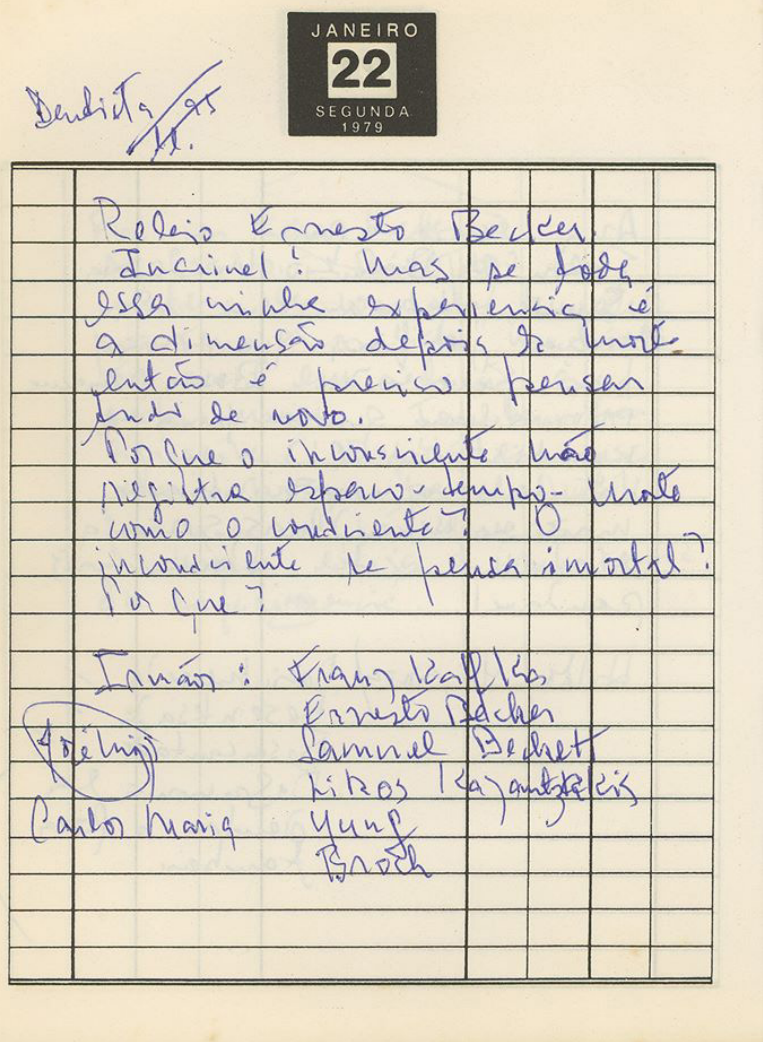

Fonte: Instituto de Estudos da Linguagem - Unicamp. Acervo Hilda Hilst

\footnotetext{
4 Esta entrevista é resultado da participação de Hilda Hilst no curso homônimo ao título de seu livro Feminino singular: a participação da mulher na literatura brasileira contemporânea, promovido no primeiro semestre de 1987 pelo Arquivo Público e Histórico do Município de Rio Claro - SP.

5 Na década de 1990, Hilda Hilst vendeu grande parte de seu acervo - manuscritos, anotações, cadernos, agendas - para o Centro de Documentação Cultural Alexandre Eulálio, da Unicamp. Observa-se aí um dedicado trabalho de elaboração de seus temas e suas personagens, indicando que ela pensava sua obra durante um longo período, e pensava escrevendo. É interessante encontrar também nesse material reflexões agudas sobre o seu próprio trabalho, talvez para suprir o que ela considerava insuficiência de leitura e crítica.
} 
No livro, considerado pelo próprio Becker como sua primeira obra madura, apoiado em Freud, Jung e Otto Rank, ele apresenta sua tese de que a morte é a principal e mais determinante inquietação que move o ser humano, que o faz avançar em suas atividades, mas que é ao mesmo tempo fonte de suas mais profundas angústias. A luta contra a morte estará, portanto, no cerne da vida humana. Becker diz:

A perspectiva da morte, disse o Dr. Johnson, impõe uma concentração admirável da mente. A tese principal deste livro é que ela faz muito mais do que isso: a ideia de morte, o temor a ela, persegue o animal humano como nenhuma outra coisa: ela é um dos maiores incentivos da atividade humana - atividade em grande parte destinada a evitar a fatalidade da morte, a vencê-la negando de algum modo ser ela o destino final do homem. (BECKER, 1976, p. 49)

Becker aponta para a essência paradoxal do homem: o fato de ele ser meio animal, meio simbólico. O homem possui uma identidade simbólica que o destaca do restante da natureza, ele é peculiar e diferente dos outros animais, no entanto, ao mesmo tempo, "o homem é um verme e comida para verme” (BECKER, 1976, p. 45). Becker assinala então que o homem está bipartido: sobressai-se na natureza com originalidade e soberania, mas a qualquer dia estará "sob uns poucos palmos de terra a fim de, cega e estupidamente, apodrecer e desaparecer para sempre” (BECKER, 1976, p. 45). Eis a nossa mais terrível consciência, aquela da qual tentamos nos afastar cotidianamente, mas que nos sopra, a cada dia, seu hálito quente a alardear sua presença.

Interessante que esse paradoxo fundamental do homem o faça oscilar entre o que há de mais elevado e o que há de mais baixo em matéria humana. Como Becker observa, a consciência desenvolvida do homem o faz considerar-se um pequeno deus na natureza, ele pensa estar reservado a um destino heroico. Ao mesmo tempo, Becker dedica uma extensa reflexão a respeito da corporalidade do homem e de um orifício específico que o faz tombar de toda e qualquer pretensão de majestade, em passagens que se assemelham em muito a trechos de textos hilstianos: "O mais estranho e degradante de tudo é a constatação de que o corpo tem, localizado na extremidade inferior, atrás e fora de visão, um orifício do qual saem cheiros fétidos" (BECKER, 1976, p. 51). Em outro trecho: "O ânus e seu incompreensível e repulsivo produto representam não só determinismo e servidão físicos como o destino de tudo o que é físico: decadência e morte" (BECKER, 1976, p. 51). E, para completar, ele faz uma citação filosófica: "Como Montaigne disse, no mais alto trono do mundo o homem se senta sobre o traseiro" (BECKER, 1976, p. 50).

Não podemos negar esse orifício, embora asqueroso e fétido, ele está ali e tem uma função. Ele é nosso canal de excreção, nossa vergonha erógena, o sol vital que nos queima. A morte também, embora negada, embora reprimida e escondida como o ânus no meio das carnes, não nos poupa de sua dimensão espetacular, leonina. Os mortos estão por todo lado, e falar da morte não deve ser outra coisa que falar da vida. Se resta algo, seu resíduo é ininteligível e inconformável.

Por indomável que seja, esse resíduo, no entanto, tantas vezes será transformado em filosofia, poesia, ${ }^{6}$ arte. Para finalizar, ficamos com um trecho do livro A barca da morte [1933] (1985), de

6 No ensaio "Georges Bataille e as formações do abjeto", Marcelo Jacques de Moraes discorre a respeito dos métodos de excreção e de apropriação do dejeto, do seu processo de homogeneização ou da circulação de sua heterogeneidade. Segundo Jacques de Moraes, para Bataille a filosofia e a poesia seriam modalidades de apropriação do excremento, ao operar um processo de sublimação, a serviço de "construtos civilizatórios". A filosofia realizaria uma apropriação intelectual do dejeto, reduzindo sua "resistência concreta a uma dimensão conceitual abstrata". Sobre a poesia, reproduzimos todo trecho da reflexão de Jacques de Moraes: "A poesia, a seu turno, leva frequentemente, em sua autonomia, à constituição de uma 'homogeneidade estética'; pois, ao converter a realidade vulgar em realidade superior, o grotesco em sublime, o informe em forma, o abjeto em ideia, dispondo, assim, o dejeto como forma acabada - e, portanto como ideia pronta para o consumo, como mercadoria -, ela não pode evitar sua 'incorporação em um sistema intelectual homogêneo, isto é, uma anulação hipócrita do caráter excremencial"” (MORAES, 2005, p. 114). Entretanto, quando falarmos neste artigo de poesia, trataremos sobretudo do que Bataille chamou, em A noção de despesa, de poesia da perda, em sua fase 
D.H. Lawrence, autor que, tal como Hilda Hilst e Georges Bataille, tocou em feridas profundas do humano. Se será vão tentar evitar o que vem ao nosso encontro, deve ser preciso, então, construir nossa barca:

Morrendo, estamos morrendo, agora só nos resta aceitar a morte, e construir a barca

da morte que nos leve a alma na mais longa viagem.

Uma pequena barca, com remos e comida

e pequenos pratos, e todo o apetrechamento

pronto e necessário à alma de partida.

Agora, lança à água a pequena barca, agora, que o corpo morre

e a vida parte, lança a alma frágil

na frágil barca da coragem, na arca da fé,

com os mantimentos, as pequenas caçarolas

e as mudas de roupas;

no negro deserto do dilúvio

nas águas do fim

no mar da morte, onde navegamos ainda,

às escuras, porque não temos leme nem existe porto. ${ }^{7}$

(LAWRENCE, 1985).

\section{Possibilidade da morte}

O ser humano encontra-se no limite do eu ao nada, ideia que Bataille explora em seu ensaio sobre Hegel, o sacrifício e a morte, em que o Nada se manifesta como ação negativa ou criativa, no momento em que se instala a morte na natureza, portanto como um vetor da existência humana, também de seu dilaceramento absoluto. Bataille cita Kojève, a partir de quem ele aborda Hegel neste ensaio:

o pensamento e o discurso, revelador do real, nascem da Ação negadora que realiza o Nada aniquilando [anéantissant] o Ser: o ser dado do Homem (na Luta) e o ser dado da Natureza (pelo Trabalho - que resulta aliás do contato real com a morte na Luta). Quer dizer então que o próprio ser humano não é nada além dessa Ação: ele é a morte que vive uma vida humana (KOJÈVE apud BATAILLE, 2013, s/p).

Essa frase final é citada três vezes ao longo do ensaio, apostando na constituição inseparável entre morte, vida e humano, tripé da experiência do real, por vezes forçada ao limite até a experiência do impossível, de dissolução e de apagamento do sujeito.

Se a morte, no entanto, é uma experiência extrema, ela é ainda assim possibilidade, "uma vez que só o homem "pode" morrer, de sorte que a morte ainda é para ele uma possibilidade, uma potência, porque a rigor ela é a possibilidade da impossibilidade.” (BATAILLE, 2014, p. 24), como sublinha

excremencial, e portanto em seu sentido vizinho ao de sacrifício. Bataille diz: "O termo poesia, que se aplica às formas menos degradadas, menos intelectualizadas da expressão de um estado de perda, pode ser considerado como sinônimo de dispêndio: significa, com efeito, do modo mais preciso, criação por meio da perda" (BATAILLE, Georges Bataille e as formações do abjeto 2013, p.23).

7 Tradução para a edição portuguesa de Rui Rosado. Lisboa: Hiena Editora, 1985.

We are dying, we are dying, so all we can do/ is now to be wiling to die, and to build the ship/of death to carry the soul on the longest journey./ A little ship, with oars and food/ and little dishes, and all accoutrements/ fitting and ready for the departing soul./ Now launch the small ship, now as the body dies/ and life departs, launch out, the fragile soul/ in the fragile ship of courage, the ark of faith/with its store of food and little cooking pans/ and change of clothes, upon the flood's black waste/ upon the waters of the end/ upon the sea of death, where still we sail/ darkly, for we cannot steer, and have no port. 
Raúl Antelo, citando Maurice Blanchot, no prefácio à edição brasileira de $\mathbf{O}$ erotismo. Ou seja, a experiência do impossível, como a morte de fato, são movimentos e não paradas, não se pode conhecê-las de fato senão por subterfúgios de visibilidade.

Ora, são justamente as experiências de intensidade máxima que Bataille vai valorizar, como empreendimento de deslocamento e dessubjetivação. Moraes e Paixão, na apresentação à tradução dos poemas de $\mathbf{O}$ arcangélico, vão sublinhar esta tendência radical que já se encontrava nos ensaios filosóficos de Bataille: 'Estranha eloquência, a desse 'eu lírico' que se apaga em cada verso, condenando seu próprio enunciado ao mais profundo silêncio. Aliás, é em torno do silêncio que essa poesia gravita o tempo todo, como que buscando avizinhar-se da morte.” (BATAILLE, 2015, p. 19).

A morte consiste, portanto, no lugar privilegiado para essa experiência extrema - impossibilidade possível -, e parece oportuno que tenha sido tema central do único livro de poemas de Bataille, em que o pensamento ensaia questões-chave de sua filosofia de forma ainda mais selvagem. Igualmente notável que Hilda Hilst, interessada nas questões-limite do humano, tenha dedicado um livro de poemas à morte, também um dos grandes temas de sua obra. E, embora o tratamento a essa questão tenha adquirido tonalidade diferente entre os dois autores, o espectro incansável da "morte que vive uma vida humana", do ser que vive para a morte, ronda o limite que abre para a imensidade esmagadora, "criminosa", de modo que Hilda Hislt e Bataille delinearam, de certa forma, essa vastidão (des)conhecida, apostando na dramatização da morte, como condição da vida, e na mortalidade como condição da poesia.

Na apresentação às odes, Alcir Pécora (apud HILST, 2013, p. 9) comenta: “Construir a interlocução da morte significa, para Hilda, permanecer atento ao seu trote de cascos enfaixados, que trabalham em silêncio pela aniquilação. Importa sobretudo a observação minuciosa de seu lento consumir da vida, à maneira da ferrugem, que não dorme nunca". Assim, este encontro, embora de expectativa assustadora, envolve também certa suavidade, um movimento de lentidão intensiva no trajeto até a hora marcada. Trata-se nestas odes de uma "espia cuidadosa da morte em vida", mais uma vez nas palavras de Pécora, apontando para a observação tateante deste eu poético, este o seu método de trazer conforto frente às indagações sucessivas e infindáveis.

Uma série de perguntas, portanto, é feita para esta interlocutora: "Como virás, morte minha?", "Como te emoldurar?", “Como me tomarás?", "Por que te desprezei?", "Por que te fiz rainha?", “Quando é que vem?”, “Onde nasceste, morte?”, “Que cores, ocaso e monte?”, "Por que não partes?”, “Que rumos? Que calmarias?”, "Me levas pra qual desgosto?”, “Há luz, há um deus que me espia?”, "Por que me fiz poeta?”, “Devo eu morrer?”, “Deves me perseguir?”. E aqui o único momento em que a morte digna-se a prestar contas a que veio: "Que queres, morte,/ Vestida de flor e fonte?// - Olhar a vida".

Mas a morte não chega de fato, e, se chegasse, já não encontraria uma poeta falante, capaz de dizêla. Daí a linguagem, diante da morte, ser sempre linguagem da iminência. A morte é miragem, zona de contemplação, interlocutora fantasma. Interpela-se a morte: "Pertencente te carrego:/ Dorso mutante, morte. / Há milênios te sei/ E nunca te conheço.” (HILST, 2013, p. 31), ressaltando seu caráter esquivo, inapreensível, porque, por mais que possamos contemplar a sua aproximação, caminhar em direção a ela enquanto ela caminha em nossa direção, este encontro é fugidio e incompleto, um raio de luz numa noite escura. De modo que a consciência da morte - pré-requisito do ser - não pode prescindir da representação, do espetáculo, "sem cuja repetição poderíamos, diante da morte, permanecer estrangeiros, ignorantes, como aparentemente o são os animais. Nada é menos animal, de fato, do que a ficção, mais ou menos distanciada do real, da morte" (BATAILLE, 2013, s/p).

Assim se a morte, como experiência extrema, é algo que escapa ao símbolo e excede à representação, é tema, no entanto, de uma enxurrada de publicações, dramatizações, ficções, e eixo central que conduz a vida que conduz à morte. No ensaio Tonalités mortelles (2016), de José Thomaz Brum, 
somos apresentados a algumas paisagens da morte a partir de grandes figuras do pensamento. Segundo Thomaz Brum, para Giácomo Casanova, a vida é uma espécie de ópera, um divertimento musical. E a morte, por sua vez, é a intrusa que vem interromper os prazeres da vida. Para Vladimir Jankélévitch, a morte é um monstro que revela o não-ser, e é tão difícil pensá-la como é difícil pensar Deus, o tempo, a liberdade ou o mistério musical. Para o romeno Emil Cioran, a "utilidade" da morte é denunciar a ilusão da vida, e morrer - o que sem nenhum esforço fazemos - pode ser uma vantagem. O ensaio fecha com a visão de Annemarie Schwarzenbach sobre a morte, afirmando que ela é inelutável, incompreensível, inumana. Bataille e Hilst também deixaram sua contribuição neste campo, explorando seu imaginário, demarcando a consciência da morte, e apontando para a impossível tarefa de lhe atribuir sentido, sua incoerência abissal. Hilst diz sobre a morte:

\title{
XIII
}

Funda, no mais profundo do osso.

Fina, na tua medula

No teu centro-ovo. Rasa, poça d'água

Tina. Longa, pele de cobra, casca.

Clara numas verticais, num vazado sol

Da tua pupila. Paciente, colada às pontes

Onde devo passar atada aos pertences da vida.

Em tudo és e estás.

meus olhos são raios cegos

meu coração é o céu

onde a tempestade eclode

(HILST, 2013, p. 41)

E Bataille:

\author{
eu sou o morto \\ o cego \\ a sombra sem ar \\ como os rios no mar \\ em mim o ruído e a luz \\ se perdem sem fim \\ eu sou o pai \\ e o túmulo \\ céu (BATAILLE, 2015, p. 39) ${ }^{8}$
}

\section{Incorporada morte}

Como horizonte de expectativa, destino inalcançável a que se tende, vazio e ausência, e por sua inclinação erótica, a morte situa-se no campo do fetiche e do desejo, na medida em que o homem é atraído pelo que o repugna e o assusta. E a interdição de que é alvo, que trata da vontade do homem de querer durar, impõe sobre a morte os limites que ativam o desejo. Pierre Klossowski (1936, p. 5), no ensaio "O monstro", do primeiro número de Acéphale, ${ }^{9}$ observa: "não é na presença, mas

8 je suis le mort/ l'aveugle/ l'ombre sans air// comme les fleuves dans la mer/ en moi le bruit et la lumière/ se perdent sans finir// je suis le père/ et le tombeau/ du ciel.

9 Acéphale [A Conjuração Sagrada], de 24 de junho de 1936. Neste ensaio, Klossowski reflete a respeito dos "modos de espera" em Sade, suas personagens estando inseridas em um universo que renega a imortalidade da alma. Ele observa: "negando assim a elaboração temporal de seu próprio eu, sua espera as recoloca paradoxalmente no estado de possessão de todas as possibilidades de desenvolvimento em potência, que se traduz por seu sentimento de potência incondicionada" (KLOSSOWSKI, 1936, p. 6). A isso Klossowski chamará de candidatura à monstruosidade integral. 
na espera dos objetos ausentes que se gozará desses objetos - isso quer dizer que se gozará desses objetos destruindo sua presença real”, de modo que há um esforço para se escapar ao objeto da espera. Ora, para reforçar a hipótese de que a Lei ativa nosso próprio desejo, Bataille cita Sade, em Cento e vinte dias de Sodoma: "a verdadeira maneira de estender e multiplicar seus desejos é querer imporlhe limites" (SADE apud BATAILLE, 2014, p.72). Assim, o homem não apenas teme, mas também busca e deseja a morte, por vezes tendendo a ela voluntariamente, consciente ou inconscientemente, e opera no sentido de criar um rico imaginário para a sua espera. Mas a morte não chega de fato, ela é da ordem do desejo. É também na epígrafe ao ensaio de Klossowski que lemos a dramaturgia que Sade criou para a sua morte:

Será enviado um mensageiro ao senhor Lenormand, mercador de madeira... para pedir-lhe que venha ele próprio, com uma charrete, buscar meu corpo para ser transportado... ao bosque de minhas terras da Malmaison... onde quero que seja colocado, sem cerimônia alguma, na primeira mata de corte cerrada que se encontra à direita no dito bosque... Minha fossa será aberta nessa mata pelo caseiro da Malmaison, sob a inspeção do Sr. Lenormand, que só deixará meu corpo após tê-lo colocado dentro da dita fossa... A fossa uma vez recoberta, serão semeadas bolotas de carvalho, a fim de que, em seguida, o terreno da dita fossa se achando reguarnecido e a mata se achando cerrada como era antes, os vestígios de meu túmulo desapareçam da superfície da terra, como me gabo de que minha memória se apagará do espírito dos homens. (SADE apud KLOSSOWSKI, 1936, p. 5)

O ritual que Sade deixa registrado em seu testamento tem como objetivo final o apagamento do indivíduo, seu descolamento da memória da humanidade, o que soa coerente com o projeto de desindividuação e dissolução do sujeito que Bataille atribui à poesia e à literatura (ao erotismo, ao sacrifício, à morte), e assim Sade ensaia uma saída literária da vida. Bataille, no ensaio que dedica a Sade em "A literatura e o mal", ${ }^{10}$ discorre a respeito deste testamento, na chave do que ele chama de "vontade de destruição de si" como sentido da obra sadiana: "o sentido de uma obra infinitamente profunda está no desejo que o autor teve de desaparecer (de se dissolver sem deixar nenhum vestígio humano): pois não havia nada mais à sua altura" (BATAILLE, 2015, p.104-105). Mas é curioso que tenha se dado ao trabalho de deixar registrado a teatralização de seu enterro, como grand finale da vida, seu clímax, ponto máximo, o que por outro lado contribui para a consolidação de sua memória. E assim como o desejo final de Kafka não foi respeitado e seus manuscritos sobreviveram, Sade foi enterrado no cemitério do asilo de Chareton, em uma cova com uma cruz e sem nenhuma inscrição. E, mais que isso: sua obra eternizou-se.

Em Contos d'escárnio, textos grotescos, o testamento de Crasso, por sua vez, reivindica um ritual funerário bastante criativo. Ele dispensa todo culto sobre a morte e apronta uma cerimônia cujo centro gravitacional é o desejo sexual: o cadáver imaginado, embora morto para algumas coisas, continua vivíssimo quando o assunto é ter o sexo estimulado. Em mais esta passagem, fica claro que as cenas pornográficas hilstianas são, em boa parte, uma grande comédia:

Quando eu morrer, quero que ao invés das bolinhas de algodão que usualmente colocam nas narinas do morto, que você providencie bolinhas de pentelho virgem. Sei que será uma estafante tarefa porque primeiro: não há virgens. Segundo: as que seriam virgens seriam impúberes e portanto sem pentelhos: glabras. Vá pensando nisso tudo. Outra coisa importante: pinte uma vagina dentro de uma casca de ovo, com nuances bleu foncé e negro, e estando eu morto coloque a pequena tela no bolso da minha calça. Do lado direito. Enquanto coloca, alise com brandura meu caralho-prega (este que eu agora aliso enquanto te escrevo e que está tudo aquilo túrgido, duro, aceso, pulsante, vibrátil, túmido, sem que os amigos ao redor do esquife percebam, para não ficar constrangedor para mim, percebes?) (HILST, 2014, p. 106).

10 Retomada do artigo "Le secret de Sade" [O segredo de Sade], publicado nos números 15-16 (ago./set.) e 17 (out.) da revista Critique, em 1947. (Nota dos editores da edição brasileira de La littérature et le mal). 
Se a morte, porém, tão banal e cotidiana quanto extrema e insana, é representada de forma solene, também ela está ligada ao aniquilamento do ser e à podridão do corpo. O cadáver - o que resta do ser destituído de vida - em um primeiro momento semelhante ao corpo vivo, está em trânsito para virar matéria fétida e comida de verme, quando então já não terá nome algum na língua humana. Mas há algo de muito estranho, bastante perturbador: aquele recipiente que abrigava a vida de um ser, sua identidade de tantas formas manifestada, agora é vazio, ausência, impossibilidade, "nada". Mas o cadáver é sempre um terceiro, e, por isso, espetáculo da morte. Bataille discorre sobre este espanto:

Na morte de outro alguém, enquanto esperávamos, nós que sobrevivemos, que se mantivesse a vida daquele que, perto de nós, repousa imóvel, nossa espera, de repente, se resolve em nada. Não que um cadáver seja nada, mas esse objeto, esse cadáver está marcado desde o princípio pelo signo nada. Para nós que sobrevivemos, esse cadáver, cuja purulência próxima nos ameaça, não corresponde ele próprio a nenhuma expectativa semelhante àquela que tínhamos desse homem estendido, quando estava vivo, mas a um temor: assim, esse objeto é menos que nada, pior que nada. (BATAILLE, 2014, p. 82).

Da morte não sabemos nada; assistimos todos os dias à morte. Alguns dias a morte está ao nosso lado, e podemos mirá-la bem de perto, esquadrinhá-la. A morte, esta velha senhora do tempo, cuja zona de influência estende-se indistintamente entre os distintos, condição da vida e da poesia. A morte, a quem Hilda Hilst dedicou odes, por sua ilustre presença, por sua passagem célebre. Voltando a pensar na personagem de Ivan Ilitch, a morte é a agonia de um burocrata, o jogo de uíste, a decência da vida, a hipocrisia das convenções sociais, a morte é a casa nova, a queda da escada, é a dor no rim, é a indiferença da esposa e dos filhos, é a cumplicidade do criado Gerasim. Seu obituário no jornal, e o seu velório.

Há algo que a morte leva, algo que acontece no corpo e nos deixa perplexos, seu componente sagrado: ela é o que não deve ser tocado, embora de forma recorrente seja alvo de profanação. A morte é ameaça, desconfiança e solenidade, mas é também náusea, repugnância e nojo. O corpo como primeiro espelho da morte: morrem-se dedos, mãos, braços, peitos, ancas, face, pés, pernas... e o que resta? O que cabe à vida e o que cabe à morte: o que nos pertence?

XI

Levarás contigo

Meus olhos tão velhos?

Ah, deixa-os comigo

De que te servirão?

Levarás contigo

Minha boca e ouvidos?

Ah, deixa-os comigo

Degustei, ouvi

Tudo o que conheces

Coisas tão antigas.

Levarás contigo

Meu exato nariz?

Ah, deixa-os comigo

Aspirou, torceu-se

Insignificante, mas meu.

E minha voz e cantiga?

Meu verso, meu dom

De poesia, sortilégio, vida?

Ah, leva-os contigo.

Por mim. (Hilst, 2013, p.39) 
Algum desapego se faz necessário, pois, à exceção de Lázaro, a quem Jesus ordenou que retornasse à vida, e à exceção do sol, que morre todos os dias para voltar a nascer no dia seguinte, a morte não parece muito afeita a devolver aquilo que tomou. Assim, nos rendemos: vem, morte, toma aquilo que é teu, pois, condenados de antemão, e sem a esperança de sermos absolvidos, com ansiedade aguardamos o dia em que, de forma silenciosa ou explosiva, pronunciarás o chamado final. Que a terra nos seja leve. 


\section{Referências}

BATAILlE, Georges. A história do olho. Tradução de Eliane Robert Moraes. São Paulo: Cosac Naify, 2003.

BATAILLE, Georges. O erotismo. Tradução de Fernando Scheibe. Belo Horizonte: Autêntica, 19572014.

BATAILLE, Georges. A literatura e o mal. Tradução Fernando Scheibe. Belo Horizonte: Autêntica, 2015.

BECKER, Ernest. A negação da morte. Tradução de Otávio Alves Velho. Rio de Janeiro: Nova Fronteira, 1976.

BRUM, José Thomaz. Tonalités mortelles. Alkemie, v. 2, n. 18, p. 65-67, 2016.

COELHO, Nelly Novaes. Um diálogo com Hilda Hilst. In: COELHO, N. N. et al. Feminino singular: a participação da mulher na literatura brasileira contemporânea. São Paulo: GDR; Rio Claro, SP: Arquivo Municipal, 1989.

DINIZ, Cristiano (Org). Fico besta quando me entendem. São Paulo: Editora, 2013.

HEBREUS: 9:27. Bíblia: tradução ecumênica. São Paulo: Paulinas, 2002.

HILST, Hilda. Fluxo-floema. São Paulo: Editora Globo, 2003.

HILST, Hilda. Da morte. Odes mínimas. São Paulo: Editora Globo, 2013.

HILST, Hilda. Pornochic - O caderno rosa de Lori Lamby/ Contos d'escárnio textos grotescos/ Cartas de um sedutor. São Paulo: Editora Globo, 2016.

FOUCAULT, Michel. Prefácio à transgressão. In: Ditos e Escritos III. Rio de Janeiro: ForenseUniversitária, 2001.

KLOSSOWSKI, Pierre. O monstro. Acéphale - A conjuração sagrada, n. 1, 1936.

LAWRENCE, D. H. A barca da morte. Tradução de Rui Rosado. Lisboa: Hiena Editora, 1985.

MORAES, Marcelo Jacques de. Georges Bataille e as formações do abjeto. Revista Outra travessia 5. IIha de Santa Catarina, $2^{\circ}$ sem. 2005, 107-120. Disponível em:

https://www.academia.edu/10992405/Georges_Bataille_e_as_forma\%C3\%A7\%C3\%B5es_do_ abjeto. Acesso em: 13 jun. 2017.

RESSOUNI-DEMIGNEUX, Karim. Fin du XVIII siécle - La Révolution libère les pulsions destructrices. Sade - Attaquer le soleil. Paris: Beaux Arts Éditions, 2014. p. 17-20. 